\title{
PREVALENSI KARIES GIGI SULUNG ANAK PRASEKOLAH DI KECAMATAN MALALAYANG KOTA MANADO
}

\author{
Christy N. Mintjelungan \\ Program Studi Pendidikan Dokter Gigi Fakultas Kedokteran \\ Universitas Sam Ratulangi Manado \\ Email: mintjelunganchristy@yahoo.co.id
}

\begin{abstract}
Dental caries is a disease of dental hard tissue characterised by demineralization of the inorganic substances and dissolving of the organic substances. The prevalence of dental caries in pre-school children is still high which may due to the improper way of teeth brushing as well as consuming cariogenic foods. This study aimed to determine the prevalence of dental decidious caries status among pre-school children in Malalayang district, Manado. This was a descriptive observational study with a cross-sectional approach. This study was carried out in July 2012. The data were obtained by using questionnaires and observation. The population in this study was all kindergarten pupils (788 children) in Malalayang district and the number of samples were 90 children. Data were obtained from primary and secondary data. The results showed that the prevalence of dental caries was $90 \%$ with the average index def- $t=6.99$. Conclusion: There was a very high prevalence of dental caries among kindergarten pupils in Malalayang district, Manado.
\end{abstract}

Keywords: prevalence, dental decidious caries, pre-school children.

\begin{abstract}
Abstrak: Karies gigi adalah penyakit jaringan keras gigi yang ditandai dengan terjadinya demineralisasi substansi anorganik dan penghancuran substansi organik. Prevalensi karies gigi anak usia prasekolah yang masih tinggi disebabkan antara lain kebiasaan menyikat gigi yang tidak sesuai prosedur serta kegemaran mengonsumsi makanan kariogenik. Penelitian ini bertujuan untuk mengetahui prevalensi karies gigi sulung pada anak prasekolah di kecamatan Malalayang kota Manado. Metode penelitian yang digunakan ialah deskriptif observasional dengan pendekatan potong lintang. Penelitian ini dilakukan pada bulan Juli 2012. Pengumpulan data dilakukan dengan kuesioner dan observasi. Populasi penelitian yaitu seluruh murid Taman Kanak-kanak di kecamatan Malalayang yang berjumlah 788 anak. Sampel yang diambil sebanyak 90 anak. Data penelitian ini diperoleh dari data primer dan sekunder. Hasil penelitian menunjukkan bahwa prevalensi karies gigi sulung sebesar $90 \%$ dengan indeks rata-rata def-t $=6,99$ yang berarti rata-rata setiap anak memiliki 7 gigi yang mengalami karies. Simpulan: Prevalensi kareis gigi sulung pada murid Taman Kanak-kanak di kecamatan Malalayang kota Manado tergolong sangat tinggi.
\end{abstract}

Kata kunci: prevalensi, karies gigi sulung, anak prasekolah.

Sampai saat ini karies gigi pada anak masih merupakan masalah utama kesehatan gigi dan mulut dengan prevalensi yang masih tinggi. ${ }^{1}$ Hasil penelitian Octiara ${ }^{2}$ pada 67 anak di Panti Pungai Binjai menunjukkan bahwa prevalensi karies gigi sulung anak usia 2-5 tahun sebesar $84,21 \%$. Anak usia prasekolah merupakan salah satu kelompok rentan terhadap penyakit gigi dan mulut karena umumnya masih mempunyai perilaku atau kebiasaan diri yang kurang menunjang terhadap kesehatan gigi. Berdasarkan data Riset Kesehatan Dasar (RISKESDAS) Nasional 2007, Provinsi 
Sulawesi Utara berada pada urutan keempat tertinggi yang memiliki masalah gigi dan mulut $(29,8 \%) .^{3}$ Kota Manado memiliki prevalensi karies aktif sebesar 52,6\% dengan prevalensi terbesar di kota Manado mencapai $70,2 \%{ }^{4,5}$

Menurut Biechler dan Snowman yang dikutip oleh Patmonodewo (2003), yang dimaksud anak usia prasekolah adalah anak-anak yang berusia 3-6 tahun. Yang berusia 3 tahun biasanya mengikuti program kelompok bermain sedangkan yang berusia 4-6 tahun biasanya mengikuti program Taman kanak-kanak. Anak usia prasekolah mempunyai ciri khas yaitu sedang menjalani proses tumbuh kembang termasuk tumbuh kembang gigi sulung dan gigi tetap, banyak melakukan aktivitas jasmani, dan mulai aktif berinteraksi dengan lingkungan sosial maupun alam sekitarnya. ${ }^{6}$

Gigi pada anak prasekolah umumnya masih merupakan gigi sulung (primary teeth) dengan struktur dan morfologi gigi yang rentan terhadap karies. Menurut Maulidta, ${ }^{7}$ prevalensi karies gigi anak usia prasekolah yang masih tinggi disebabkan antara lain karena kebiasaan mereka menyikat gigi tidak sesuai prosedur serta kebiasaan mengkonsumsi makanan yang kariogenik. Selain itu, anak masih sangat tergantung pada orangtua dalam hal menjaga kebersihan dan kesehatan giginya.

Gigi sulung bila tumbuh lengkap berjumlah 20 buah, masing-masing 10 gigi di rahang atas dan 10 gigi di rahang bawah yang terdiri dari 4 gigi seri (insisivus), 2 gigi taring (kaninus), dan 4 gigi geraham (molar). Gigi-gigi pertama biasanya erupsi setelah 6-7 bulan sesudah kelahiran dan semua gigi-gigi sulung biasanya erupsi pada usia 2,5 atau 3 tahun. Dengan demikian, sejak usia ini anak tersebut sudah siap mengunyah makanan dengan sempurna. ${ }^{8}$

Karies gigi adalah proses pembusukan pada gigi yang menimbulkan lubang pada gigi. ${ }^{9}$ Karies gigi dimulai dari email hingga ke dentin dan disebabkan oleh bakteri tertentu yang dapat memfermentasikan karbohidrat seperti sukrosa dan glukosa, membentuk asam, menurunkan $\mathrm{pH}$ hingga
$<5$, dan mengakibatkan demineralisasi pada permukaan gigi yang rentan. Karies gigi dapat dialami oleh setiap orang dan dapat timbul pada satu permukaan gigi atau lebih dan dapat meluas ke bagian gigi yang lebih dalam, misalnya dari permukaan email ke dentin atau ke pulpa. ${ }^{10}$

Status karies gigi adalah suatu keadaan yang menggambarkan persentase dan derajat keparahan karies pada masyarakat berdasarkan pengalaman karies yang pernah terjadi pada setiap individu. Hal ini diukur dengan indikator dan standar penilaian yang telah disesuaikan dengan standar World Health Organization (WHO) yaitu prevalensi karies gigi dan indeks karies gigi dimana untuk gigi sulung dipakai indeks def-t dan untuk gigi tetap dipakai indeks DMF-T. Def-t adalah indeks untuk menghitung jumlah gigi yang pernah mengalami karies (caries experience) per anak, dan def-t dinyatakan baik bila def-t $=0 .{ }^{11}$

Mengingat masih tingginya prevalensi karies gigi pada anak maka penelitian ini ditujukan pada prevalensi karies gigi sulung pada anak prasekolah di Kecamatan Malalayang Kota Manado.

\section{METODE PENELITIAN}

Penelitian dilaksanakan pada Taman Kanak-kanak (TK) terpilih di kecamatan Malalayang kota Manado pada bulan Juli 2012. Jenis penelitian menggunakan pendekatan potong lintang. Populasi penelitian ialah seluruh murid TK yang berusia 3 sampai 6 tahun yang berada di kecamatan Malalayang kota Manado. Untuk membantu menjawab pertanyaanpertanyaan yang tidak dapat dijawab oleh anak-anak maka orang tua murid yang mengantar ikut diwawancara.

Berdasarkan data dari Dinas Pendidikan Kota Manado jumlah seluruh murid TK di Kecamatan Malalayang sebanyak 788 anak dari 28 TK. $^{12}$ Jadi jumlah keseluruhan populasi penelitian ini ialah 788 murid. Sampel minimal penelitian diambil dengan menggunakan rumus Lameshow et al. ${ }^{13}$ dan diperoleh 
$\mathrm{n}=90$. Subjek penelitian diperoleh dengan teknik pengambilan sampel secara acak sederhana. ${ }^{14}$

Kategori indeks def-t yang dipakai dalam penelitian ini ialah kategori WHO (2003) sebagai berikut: ${ }^{15}$

$$
\begin{gathered}
\text { Skor } \\
0,0-1,1 \\
1,2-2,6 \\
2,7-4,4 \\
4,5-6,5 \\
>6,6
\end{gathered}
$$

$$
\begin{gathered}
\text { Kategori } \\
\text { Sangat rendah } \\
\text { Rendah } \\
\text { Sedang } \\
\text { Tinggi } \\
\text { Sangat tinggi }
\end{gathered}
$$

Prevalensi karies gigi adalah persentase murid yang mengalami karies gigi pada suatu jangka waktu tertentu di kelompok masyarakat tertentu yang dinyatakan dengan:

Jumlah murid yang mempunyai pengalaman karies (def-t) Jumlah sampel murid x $100 \%$ yang diperiksa

\section{HASIL PENELITIAN}

Hasil penelitian ini berdasarkan karakteristik responden dilihat menurut usia, jenis kelamin, dan status karies gigi sulung. Distribusi responden menurut usia menunjukkan kelompok usia 5 tahun yang terbanyak $(63,3 \%)$ (Tabel 1).

Tabel 1. Distribusi responden menurut usia

\begin{tabular}{ccc}
\hline $\begin{array}{c}\text { Usia } \\
\text { (tahun) }\end{array}$ & Frekuensi & $\begin{array}{c}\text { Persentase } \\
(\boldsymbol{\%})\end{array}$ \\
\hline 4 & 7 & 7,8 \\
5 & 57 & 63,3 \\
6 & 26 & 28,9 \\
Total & 90 & 100,0 \\
\hline
\end{tabular}

Tabel 2 menunjukkan bahwa distribusi responden berdasarkan jenis kelamin lakilaki dan perempuan hampir sama banyak.
Tabel 2. Distribusi responden menurut jenis kelamin

\begin{tabular}{ccc}
\hline Jenis kelamin & Frekuensi & $\begin{array}{c}\text { Persentase } \\
(\%)\end{array}$ \\
\hline Laki-laki & 44 & 48,9 \\
Perempuan & 46 & 51,1 \\
Total & 90 & 100,0 \\
\hline
\end{tabular}

Karakteristik kesehatan gigi dan mulut responden meliputi pengalaman karies gigi sulung (def-t) dan prevalensi karies gigi sulung. Status karies gigi pada penelitian ini berdasarkan pada pengalaman karies gigi sulung responden menurut skor def-t dapat dilihat pada Tabel 3.

Tabel 3. Distribusi responden menurut skor def-t

\begin{tabular}{ccc}
\hline $\begin{array}{c}\text { Skor def-t } \\
\text { (gigi) }\end{array}$ & $\begin{array}{c}\text { Frekuensi } \\
\text { (n) }\end{array}$ & $\begin{array}{c}\text { Persentase } \\
(\%)\end{array}$ \\
\hline 0 & 9 & 10,0 \\
1 & 5 & 5,6 \\
2 & 9 & 10,0 \\
3 & 5 & 5,6 \\
4 & 7 & 7,8 \\
5 & 6 & 6,7 \\
6 & 7 & 7,8 \\
7 & 2 & 2,2 \\
8 & 8 & 8,9 \\
9 & 2 & 2,2 \\
10 & 3 & 3,3 \\
11 & 6 & 6,7 \\
12 & 6 & 6,7 \\
13 & 3 & 3,3 \\
14 & 5 & 5,6 \\
15 & 2 & 2,2 \\
16 & 1 & 1,1 \\
18 & 4 & 4,4 \\
Total & 90 & 100,0 \\
\hline
\end{tabular}


Data pada Tabel 3 menunjukkan bahwa distribusi responden yang mempunyai pengalaman karies gigi (def-t) bervariasi antara 0 (tidak ada karies gigi) sebanyak 9 responden sampai dengan 18 gigi sebanyak 4 responden.

Prevalensi karies gigi

$\begin{gathered}\text { Jumlah murid yang mempunyai } \\ \text { pengalaman karies (def-t) }\end{gathered}$
Jumlah sampel murid
yang diperiksa

$$
=\frac{81}{90} \times 100 \%=0,9 \times 100 \%=\mathbf{9 0 \%}
$$

\section{BAHASAN}

Berdasarkan penelitian yang telah dilakukan terhadap 90 orang responden didapatkan bahwa hanya terdapat kategori usia 4 sampai 6 tahun. Sebagian besar responden terdistribusi pada kelompok usia 5 tahun $(63,3 \%)$, diikuti oleh kelompok usia 6 tahun $(28,9 \%)$ dan terakhir kelompok usia 4 tahun $(7,8 \%)$. Hasil ini sesuai dengan rekomendasi WHO (2000) dalam melakukan pemeriksaan pada kelompok usia tertentu antara lain kelompok usia 5 tahun untuk gigi sulung. Usia ini menjadi usia indeks untuk gigi sulung karena proses karies gigi pada kelompok usia ini lebih cepat.

Hasil penelitian ini menunjukkan bahwa hampir semua responden berusia 4-6 tahun di kecamatan Malalayang kota Manado memiliki pengalaman karies gigi sulung dengan distribusi terbanyak pada usia 5 tahun $(63,3 \%)$. Hal ini menunjukkan bahwa kelompok usia 5 tahun rentan terhadap terjadinya karies gigi sulung karena umumnya masih mempunyai perilaku atau kebiasaan diri yang kurang menunjang terhadap kesehatan gigi dan mulut misalnya kumur-kumur air putih setelah minum susu dan makan coklat. Selain itu, anak prasekolah usia 3-6 sangat membutuhkan pendampingan orang tua terutama ibu dalam hal menjaga kebersihan gigi dan mulut terlebih lagi saat menyikat gigi. Peran ibu membantu anak menyikat gigi sangat dibutuhkan mengingat anak prasekolah usia 3-6 tahun masih memerlukan bimbingan dari orangtua. ${ }^{16}$ Menyikat gigi merupakan salah satu teknik yang paling sering digunakan untuk mengendalikan plak secara mekanis. ${ }^{17}$

\section{SIMPULAN}

Hasil penelitian menunjukkan prevalensi karies gigi sulung anak pra sekolah usia 3-6 di kecamatan Malalayang kota Manado tahun 2010 mencapai 90\% dengan rata-rata def-t 6,99 yang berarti rata-rata setiap responden memiliki 7 gigi yang mengalami karies gigi sulung. Sebagai simpulan ialah prevalensi karies gigi sulung anak prasekolah di kecamatan Malalayang kota Manado tergolong sangat tinggi.

\section{SARAN}

Dinas Kesehatan kota Manado diharapkan dapat melakukan intervensi terhadap faktor-faktor yang meningkatkan terjadinya karies gigi di masyarakat terutama anak usia sekolah, misalnya melakukan promosi kesehatan gigi dan mulut bagi orang tua terutama para ibu di Posyandu dan di sekolah Taman Kanakkanak di kecamatan Malalayang, mengadakan penyuluhan kepada guru-guru Taman Kanak-kanak dan Play Group tentang kesehatan gigi dan mulut, serta pemeriksaan gigi rutin terhadap anak-anak, khususnya yang berusia 4-6 tahun.

\section{DAFTAR PUSTAKA}

1. Al Supartinah S. Saliva dan kaitannya dengan penyakit rongga mulut anak [Pidato pengukuhan guru besar FKG UGM]. Jogjakarta: UGM; 30 Agustus 2003.

2. Octiara E, Roesnawati Y. Karies Gigi, Oral Hygiene dan Kebiasaan Membersihkan Gigi Pada Anak-anak Panti Karya Pungai di Binjai. Jurnal Kedokteran Gigi UI 2001; 6(1):18-23. 
3. Departemen Kesehatan Republik Indonesia. Riset Kesehatan Dasar Indonesia Tahun 2007. Jakarta, 2008.

4. Dinas Kesehatan Provinsi Sulawesi Utara. Riset Kesehatan Dasar Sulawesi Utara Tahun 2007. Manado, 2008.

5. Profil Kesehatan Provinsi Sulawesi Utara. Manado: Dinas Kesehatan Provinsi Sulawesi Utara; 2008.

6. Patmonodewo S. Pendidikan Anak Prsekolah. Jakarta: PT Rineka Cipta; 2003.

7. Maulidta KW. Hubungan Kebiasaan Menggosok Gigi dan Konsumsi Makanan Jajanan Kariogenik dengan Kejadian Karies Gigi pada Anak Usia Prasekolah di Taman Kanak-kanak Pondok Beringin Semarang [Tesis]. Semarang: Program Studi Ilmu Keperawatan Universitas Diponegoro; 2008.

8. Mc Donald R, Avery D. Dentistry for the Child and Adolescent (Seventh Edition). Michigan: Mosby; 2000.

9. Astoeti TE. Total Quality Management dalam Pendidikan Kesehatan Gigi di Sekolah. Jakarta: PT Raja Grafindo Persada; 2006.

10. Kidd E, Bechal SJ. Dasar-Dasar Karies
Penyakit dan Penanggulangannya. Jakarta: Penerbit Buku Kedokteran EGC; 2002.

11. Herijulianti E, Hidriani TS, Artini S. Pendidikan Kesehatan Gigi. Jakarta: EGC, 2002.

12. UPTD Dinas Pendidikan Kecamatan Malalayang. Laporan bulanan murid Taman-Kanak-kanak Kecamatan Malalayang. Manado; 2010.

13. Lemeshow S, Hosmer DW, Klar J. Besar Sampel dalam Penelitian Kesehatan.Yogyakarta: Gadjah Mada University Press; 1997.

14. Notoatmojo S. Pendidikan dan Perilaku Kesehatan. Jakarta: Rineka Cipta; 2003.

15. Peterson PF. The World Oral Report. Geneva: WHO, 2003.

16. Harini S. Usaha pencegahan penyakit dan kelainan gigi mulut anak dengan mengatur pola makan anak sejak dini. Jurnal Kedokteran Gigi Universitas Indonesia, Edisi Khusus KPPIKG XII, 2000.

17. Kidd E, Fejerskov O. Dental Caries. The Disease and Its Clinical Management (Second Edition). Oxford: WilleyBlackwell; 2008. 